\title{
Australian local governments and the early national broadband network roll-out: an online survey
}

\section{Commonwealth Journal of Local Governance \\ Issue 19: December 2016}

http://epress.lib.uts.edu.au/ojs/index.php/cjlg

\author{
Tooran Alizadeh \\ School of Environment \\ Griffith University, Australia
}

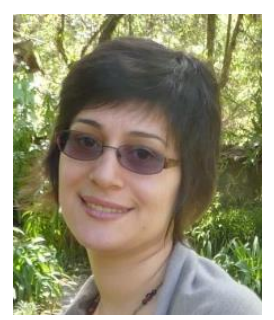

\author{
Heather Shearer \\ Cities Research Institute \\ Griffith University, Australia
}

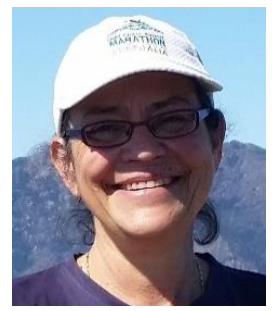

\begin{abstract}
A recent decision by the Australian Federal Government to reassess the scale of the National Broadband Network (NBN) will leave the country with a patchwork of different levels of access to the infrastructure. This intensifies the need to investigate and evaluate the implications of telecommunication at the local level. The paper opens a discussion on the different approaches taken by local government authorities towards the NBN in the early roll-out localities. Building upon the international literature, it analyses the empirical data collected from the Australian local governments involved with the early NBN roll-out using an online survey. The findings reveal an interesting diversity in the approaches taken at the local level, and show how decision-making at higher levels of government can impact local outcomes.
\end{abstract}

Keywords: Local government, telecommunication, national broadband network, Australia, highspeed broadband, local planning

\section{Introduction}

In response to shortcomings in Australia's telecommunication infrastructure (Barr 2008; Given 2008; Middleton 2009; Middleton and Chang 2008), the National Broadband Network (NBN) was announced in April 2009 to connect Australians to broadband (NBN Co Ltd 2010a). The NBN was described as the largest single infrastructure project undertaken in Australia, with an initial estimated cost of $A \$ 43$ billion (US\$33bn) (DBCDE 2010).

(C) 2016 Tooran Alizadeh and Heather Shearer. This is an Open Access article distributed under the terms of the Creative Commons Attribution 4.0 Unported (CC BY 4.0) License (https://creativecommons.org/licenses/by/4.0/), allowing third parties to copy and redistribute the material in any medium or format and to remix, transform, and build upon the material for any purpose, even commercially, provided the original work is properly cited and states its license. 
Previous studies have discussed the strong potential of telecommunication infrastructure to influence societies, economies, and urban environments worldwide (Frieden 2005; Grubesic 2010; Lee et al. 2005; Middleton 2009; Savage and Waldman 2005). More specifically, in the Australian context, the NBN has highly influenced and in turn, been greatly affected by the political setting (Given 2008; Tucker 2010). Perhaps the high point of the latter was when three independent MPs cited the NBN as one of the key reasons motivating their support for Labour over the Coalition following the hung parliament at the 2010 Federal election. On the other hand, following the 2013 Federal election, the change of the political setting had an utmost effect on the roll-out of the NBN, as the newly elected Coalition Federal Government decided to reassess the scale of the national fibre project, and put the roll-out on hold in a large number of areas. As of November 2013, only 300,000 premises listed in the earlier roll-out phases were guaranteed to be connected directly to the fibre network. Since then, the announcements made by the Coalition Federal Government confirmed that a mixed technology network will be adopted (Turnbull 2014), which means the roll-out speed could be significantly different for the rest of the country (Duke 2013; Turner 2013).

This paper avoids making any judgement about the recent political decisions around the roll-out of the telecommunication infrastructure. Instead it welcomes the current state as an opportunity to consider and analyse the efforts put into the national project over the last few years. It is perhaps time to acknowledge that despite the hefty investment on the NBN, there remains a dearth of evidence-based research to understand the specific implications of the new infrastructure. Very little attention has been paid to the specific impacts of the fast-growing telecommunication infrastructure at the local planning level (Grubesic 2012; Maeng and Nedovic-Budic 2004). Moreover, the recent decision by the Federal Government to build the national fibre project using mixed technology will have enormous impact on the distribution of telecommunication across the nation (Nirmalathas 2014). What can be said with certainty is that Coalition's NBN will leave the country with a patchwork of different levels of access to the infrastructure. This will intensify the need to investigate and evaluate the implications of telecommunication at the local level across the nation, as Australian local government authorities (LGAs) then need to respond differently based on the level of access provided in each case. For many local governments, it means that even within their own jurisdictions, they have to deal with a diverse level of access to telecommunication infrastructure.

The paper opens a discussion on the different approaches taken by Australian LGAs towards the NBN. It starts with the history of the NBN roll-out plan. It then continues with a review of broadband infrastructure and local planning in the international literature around the three main areas of implications, namely e-governance, socio-economic development, and spatial planning. This provides the foundation for the empirical part of the paper through which data were collected from the Australian LGAs involved with the early NBN roll-out using an online survey. This paper is only a beginning in the mapping of the implications for local planning of the telecommunication infrastructure, and the role 
played by the Australian LGAs in relation to the dynamics of the NBN over the last few years. The findings reveal an interesting diversity in the approaches taken at the local level, and show how decision-making at higher levels of government impact local outcomes.

\section{The national broadband network in Australia}

In April 2009, the Australian Labour Federal Government announced the formation of the National Broadband Network Company (NBN Co) to enable the broadband roll-out (NBN Co Ltd 2010b). This was shortly followed by a second announcement in which the NBN roll-out started with a three-stage trial phase in the island of Tasmania (NBN Co Ltd 2010a, 2011, 2012a). However, the roll-out of the NBN on mainland Australia started one year later in March 2010 when NBN Co announced its five first release sites as part of live trials of the network design and construction methods. The second release sites, including 14 new locations and five sites adjacent to the existing first release sites, were announced in July 2010 (NBN Co Ltd 2012a). Furthermore, in October 2011 NBN Co released a 12month national roll-out schedule plan to cover half a million premises. The schedule listed a total of 60 locations in all Australian states and territories where roll-out would begin prior to September 2012, in addition to working on the roll-out of the network that had already begun in the earlier release rounds (NBN Co Ltd 2011).

Additionally, in March 2012, the first stage of the large-scale roll-out was released to provide NBN fibre to a third of the country, including over 3.5 million homes in 1,500 communities (NBN Co Ltd 2012b). It was envisioned that the localities included in the updated schedule would be connected to the fibre-optic component before mid-2015. However, the result of the Federal election in 2013 changed the fate of the NBN roll-out. The elected Coalition Federal Government decided to reassess the scale of the national fibre project, and put the first stage of the large-scale NBN roll-out on hold. Connection dates were scrapped for almost two-thirds of premises that had been scheduled to connect to the NBN under the first phase of the nationwide fibre-to-premises roll-out. As of October 2013, only 300,000 premises listed in the first large-scale roll-out phase were still guaranteed to be connected directly to the fibre-to-premises network (Duke 2013; Turner 2013). The Coalition's version of the NBN will cover the rest of the nation using mixed technologies, with varied levels of access and final speed (Turnbull 2014).

Since its origin, the NBN has been an important part of the political debates as the two major Australian political parties have different approaches on how to deliver the NBN, particularly on the technical details and the final roll-out speed. This paper, however, focuses on understanding the uptake of Australian local governments involved with the early roll-out of the NBN. The analysis will provide an opportunity for local planning to better engage with the telecommunication infrastructure, based on the lessons learned from the NBN early roll-out experience. 


\section{Local governments and telecommunications (broadband) infrastructure}

The link between local governments and telecommunication infrastructure is an under-studied area, which is perhaps understandable given the short life of the new infrastructure and the conservative nature and restricted resources available at the local level of governance. Having said this, the following offers a brief review of the international literature to illustrate the international perspective on the subject. It then presents some of the federally funded initiatives provided in the Australian context to facilitate and guide the local implications of the NBN. A combination of the international perspective plus the federally driven Australian initiatives will then inform the design of the empirical part of the paper.

\section{International perspective}

A growing body of international literature is investigating the broad implications of telecommunications for urban and regional planning, loosely categorised under three areas of e-governance, socio-economic development, and spatial planning. The following offers a summary of these, with a focus at the local government level through which the level of uncertainty in this emerging area is well presented.

e-Governance: An extensive body of literature has investigated the impact of telecommunication infrastructure on the nature of governance at both national and local government levels. Different studies describe e-government as the use of telecommunication technologies by public organisations to manage, redefine and disseminate information, communication, and transaction relations with individual citizens, businesses and the general community at large (Edmiston 2003; Maeng and Nedovic-Budic 2004). The implementation of e-government is expected to create increased government access, better public service delivery, internal efficiency and long-term saving; and to support political accountability, and participatory democracy (Bekkers 2003; Irani et al. 2005; Jesuale 2006; Moody 2007; Steyaert 2000). However, research coming out of the US and Europe warns that, while the beneficial prospects of all levels of government are high, e-government has been penetrating at higher levels of government much more rapidly than at local government level (Edmiston 2003; Evans-Cowley and Conroy 2006, 2009; Simpson 2005). This is despite the push from the public for local governments to more actively incorporate online applications facilitating e-government in the assessment of urban planning proposals (Evans-Cowley and Hollander 2010).

Socio-economic development: Socio-economic research argues that public infrastructure is a powerful driver of business productivity, investment, economic growth and social prosperity (Aschauer 1989; Button et al. 1995; Gramlich 1994; Seitz 1995). Moreover, governments' direct and indirect involvement with broadband infrastructure worldwide is often justified by reference to social equity grounds; and is based on assumptions that the new technology-based infrastructure will increase productivity and innovation, and guarantee long-term economic competitiveness (Alizadeh et al. 2011; Martin 1999; Willson et al. 2009). This justification is founded in part on the literature generated over 
the last 10 to 15 years, describing the potential economic and social benefits of such infrastructure for businesses, households and the overall community (Galloway 2007; Hesham 2000; Katz et al. 2010; Martin and Rogers 1995). However, few empirical studies have analysed the impacts of telecommunication infrastructure post-implementation (Lee et al. 2005; Strategic Networks Group 2003). Among them, even fewer have focused at the local level, and quantified the positive socioeconomic gains as a result of the broadband network deployment (Ford and Koutsky 2005). In other words, the empirical research in this area is still in its early days; and it is extremely complex to establish beyond doubt that the infrastructure per se results in a change in an economic indicator. Even though the results should be qualified as 'preliminary evidence', broadband deployment needs to be considered as an important policy issue for any local government seeking to play an active role in the new economy.

Spatial planning: There is a consensus in the literature that spatial planning does not have specific tools to deal with telecommunication infrastructure and its urban and regional implications. Studies focusing on telework, as one of the ramifications of telecommunication, have long referred to cases where planning regulations in-place do not allow for mixed-use development, and hinder web-based home businesses (Alizadeh 2013; Handy and Mokhtarian 1995). Planning responses to other ramifications of telecommunication such as new land uses (telecom hotels and telework centres) are also documented as more varied than uniform (Alizadeh et al. 2014; Maeng and Nedovic-Budic 2004). While some local planning jurisdictions have been facilitators of the telecommunication-related land uses, others consider them as conflicting land uses. In general, the literature sees local governments as being more reactive than proactive in dealing with the emerging land uses and their potential impacts (Evans-Cowley et al. 2002). Nevertheless, there is an emerging trend to regulate ICT-related developments and issues through zoning, and designation of special districts or industrial corridors accompanied by tax-based incentives (Maeng and Nedovic-Budic 2004).

\section{Australian context}

The introduction of the NBN in Australia was followed with the development of a National Digital Strategy (DBCDE 2011b) that introduced a range of locally based initiatives to speed up some of the potential socio-economic implications of the new infrastructure at the local government level. The national strategy also included funded initiatives such as the Digital Local Government Programme to facilitate e-governance at the local level (DBCDE 2011a). Over the last few years, a growing number of LGAs have started to develop local digital economic strategies to increase the possibilities for their local communities. However, it is important to understand that the majority of Australian local governments have either not incorporated broadband opportunities in their current plans, or are only in the preliminary stages of developing a digital economy strategy (Alizadeh and Sipe 2013). The following briefly introduces the three main federally funded initiatives that aimed at guiding and advancing the implications of the NBN at the local level: 
Digital Hub Programme: The Digital Hub Programme was rolled out in 40 communities around Australia, and aimed to assist local communities to increase their online engagement and better understand the opportunities of the digital economy. Services offered included training, high-speed internet, and access to online government and education services, videoconferencing, and various other innovations.

Digital Enterprise Programme: This was rolled out to 69 communities, and aimed to provide free training and support for small to medium enterprises (SMEs) and not-for-profit groups to assist them in transitioning to delivering services online, improve productivity, reach wider markets, increase efficiency and use videoconferencing. It also aimed to assist not-for-profit groups to use social media and deliver more products and services using online means. It included a 'virtual advisor' programme to also aid indigenous people and groups, and not-for-profit organisations in regional, rural and remote areas.

Digital Local Government Programme: This programme, as part of the National Digital Economy Strategy, aimed to fund LGAs in providing innovative online services to customers and residents. The aim was for innovations that could be used by LGAs across Australia, and that helped LGAs improve the quality, availability and speed of services.

\section{Methodology}

This study used a combination of a desktop review and an online survey to collect data on the implications of the NBN in the early roll-out LGAs. The NBN Co website, and the websites of the 60 LGAs involved in the initial roll-outs of the NBN (Figure 1) were extensively monitored. The initial research involved identification of the LGAs affected by the early roll-out. The NBN Co website lists specific suburbs rather than separate LGAs, so it was necessary to match the mapped areas to specific LGAs.

An Excel spreadsheet was created with the name of the LGAs, the suburbs involved in the NBN rollout, URLs of the LGAs, and if possible, the names of the contact officer for any local digital strategy or other relevant information on the NBN, high-speed broadband, or economic strategy. The final spreadsheet contained 59 LGAs.

A short questionnaire survey was emailed to the LGAs identified in the desktop review. When names and email addresses were available, emails were sent directly to the contact officers; where not available, emails were sent to the customer service email address given on the LGA's website. One tranche of emails was sent, and three weeks later, follow up emails were sent to the non-responders. Two LGAs were not contacted directly, Brisbane City Council (information on this LGA is already known to the researchers) and the ACT government (as this is a Federal jurisdiction, and governance and funding arrangements of this region were deemed too dissimilar to the other LGAs). 
Figure 1: Australian LGAs involved in the NBN early roll-out (with those that responded to the survey crosshatched in red)

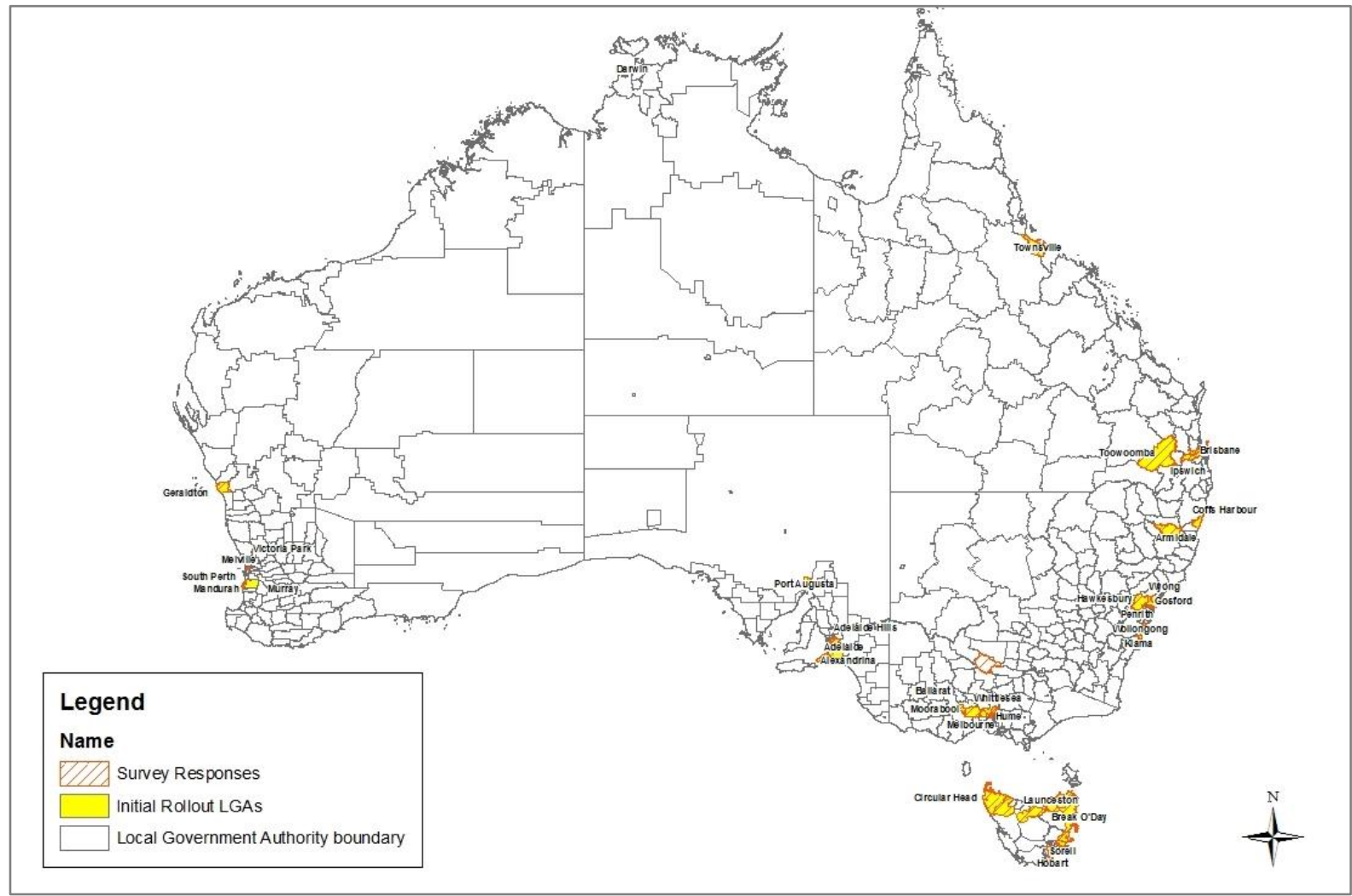

The email survey which was entitled, "LGA Responses to High-Speed Broadband" consisted of five items. Question 1 asked for the name of the LGA, and Question 5 asked if the respondent wished to be involved in further research (a short telephone interview) and if so, to provide their name, email and telephone number. The remaining three questions were based on the desktop analysis of the LGA websites, and the relevant literature, and were as follows:

- Question 2 asked "How important does council consider access to high-speed broadband?" Respondents were requested to rate this on a numerical scale, ranging from 1 (very important) to 5 (very unimportant).

- Question 3 was based on the literature review which identified the three broad areas where telecommunications might impact on local government, and asked "In which areas of the council business do you expect to see the most implications of the high-speed broadband?" The options given for this included: e-governance, land use planning, socio-economic development and other. The question allowed for multiple choices.

- Question 4 asked, "How has the council responded to the roll-out of the NBN/fast broadband?" The options were based on the literature and some of the federally initiated funds available to the local governments, and included: drafting or implementing a Digital Economy Strategy within council; hiring consultants to investigate or produce a digital economy strategy; creating a Digital Hub; joining a coalition of councils to promote digital economic strategies; not yet responded; and other. This question also allowed for multiple choices. 
The questionnaire survey was an embedded Google Form within an email, and linked to a Google Documents spreadsheet, which was updated when a survey was returned. The information from various sources was copied to a master Excel spreadsheet, which had additional information, such as size of the LGA, location (urban, regional or remote), state, links to the mapped NBN roll-out areas and a rough approximation of the proportion of the LGA included in the roll-out. Given the small number of LGAs, statistical analysis consisted of frequencies of responses only, together with graphs of responses.

Of note, the NBN early roll-out LGAs all experienced a phenomenon that all local governments across the nation will go through sooner or later. Although the speed and the technical details of the Coalition's NBN may vary from the early roll-out, the latest decision is yet to provide broadband infrastructure (one way or another) across Australia. Having said this, the online survey conducted for this study portrays a snapshot of the major implications of the new infrastructure roll-out on the first release sites which could be useful for local planning for telecommunication infrastructure across the nation and beyond. This exploratory methodology could also set the foundation for further longitudinal studies to examine the local implications of the new infrastructure over the years to come.

\section{Results: what we learned}

Of the 59 LGAs emailed, 28 LGAs responded giving a $47 \%$ response rate, which is relatively consistent with response rates for online surveys (McNulty 2008). Of those who responded, 17 stated on the email survey that they were interested in participating in a short interview. A total of ten were eventually interviewed, and the results of the interviews have been reported in a recent paper (Alizadeh and Shearer 2015).

Table 1: Responses

\begin{tabular}{|l|c|c|c|}
\hline State & Number & Responded & Interviewed \\
\hline ACT & 1 & 0 & 0 \\
\hline New South Wales & 13 & 8 & 4 \\
\hline Northern Territory & 1 & 0 & 0 \\
\hline Queensland & 8 & 4 & 3 \\
\hline South Australia & 3 & 2 & 0 \\
\hline Tasmania & 12 & 4 & 0 \\
\hline Victoria & 16 & 7 & 1 \\
\hline Western Australia & 5 & 1 & 1 \\
\hline Total & $\mathbf{5 9}$ & $\mathbf{2 6}$ & $\mathbf{9}$ \\
\hline
\end{tabular}

The LGAs responding to the survey were differentiated into the following three categories: urban (i.e. City of Gold Coast, Penrith); regional (i.e. Greater Taree, George Town); or rural (i.e. Glamorgan Spring Bay, Hepburn Shire). The population of the LGAs ranged from 4,432 in the case of Glamorgan Spring Bay (Tasmania) to 526,173 in the case of the City of Gold Coast (Queensland). It was not possible to differentiate LGAs on the basis of population however, as in some states, such as Queensland, LGAs are much larger and encompass entire cities (i.e. Brisbane and the Gold Coast), but 
in Victoria and New South Wales, for example, the capital cities, Melbourne and Sydney are differentiated into a number of smaller LGAs.

\section{Importance of access}

The majority of LGAs considered access to high-speed broadband as either highly important or highly unimportant (Figures 2 and 3). This apparently dichotomous result could be interpreted in a number of ways; including confusion when filling in the survey (two LGAs interviewed in the subsequent research phase indicated that they had incorrectly ticked "very unimportant" instead of "very important"). This may also be indicative of whether the LGA was situated in an urban area (already having access to a range of broadband options, such as cable and ADSL2) or in a rural or regional area, with limited access. A brief scan of the answers showed that all councils (with the exception of one large regional town) that ticked "very unimportant" were located in inner urban areas of major cities, such as Melbourne.

Figure 2: Population of LGAs responding to survey

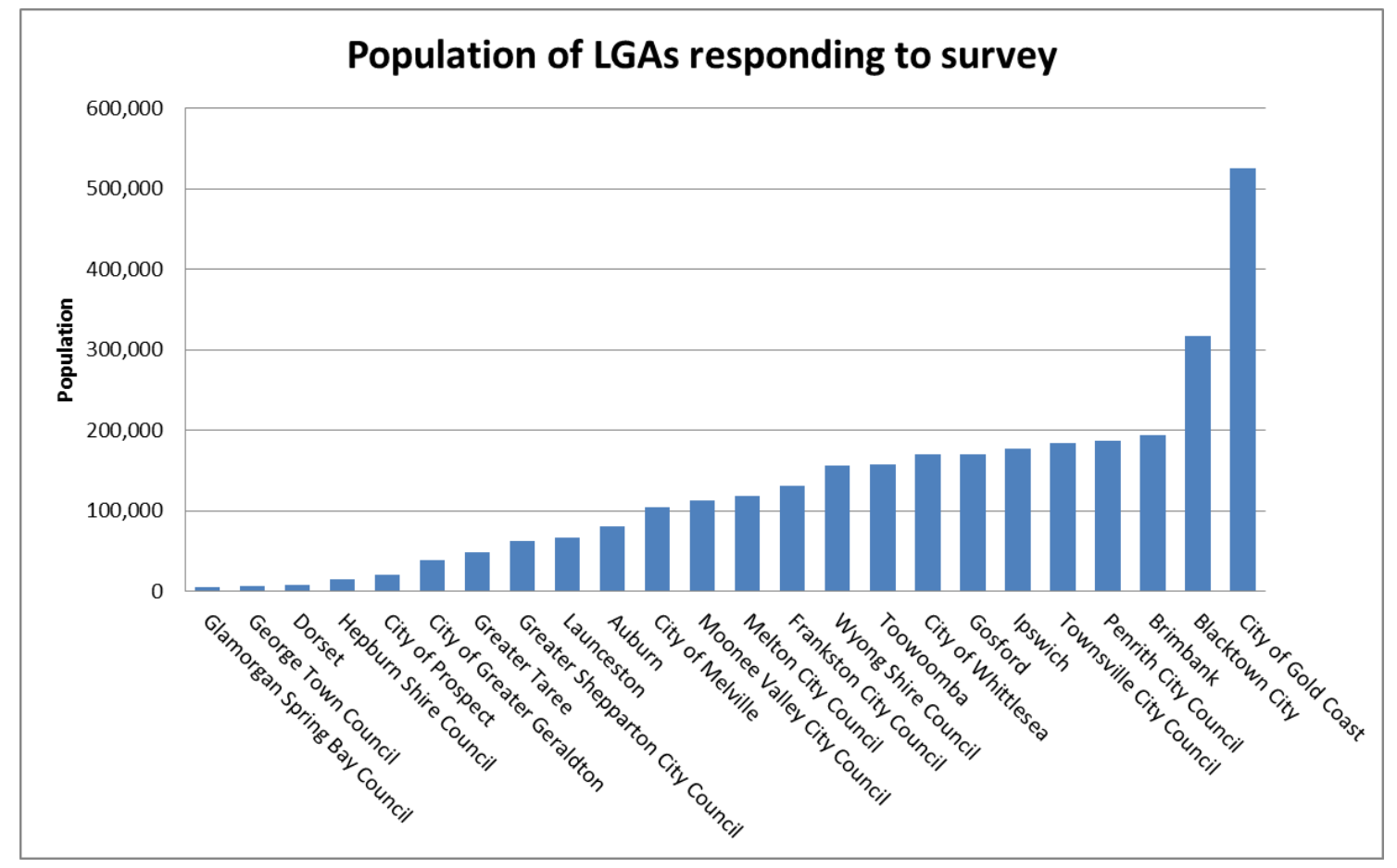

Such a bifurcated pattern (urban vs rural) links well with the previous studies (Grubesic and Murray 2004; Mack et al. 2011) investigating spatial justice implications of telecommunication with a focus on digital divide (Doctor 1994). The literature points out the complex and dynamic interplay between geography, socio-economic status, and market forces which resulted in the uneven distribution of broadband infrastructure across the US (Grubesic et al. 2011; Rowe 2003). In the Australian context also, the question of equity and spatial justice is important, as our survey results show how eager rural local governments are for the new infrastructure (considering it "very important"); this is the same infrastructure which is already easily available in major urban local government areas. 
Figure 3: Frequency of response to degree of importance given to access to high-speed broadband

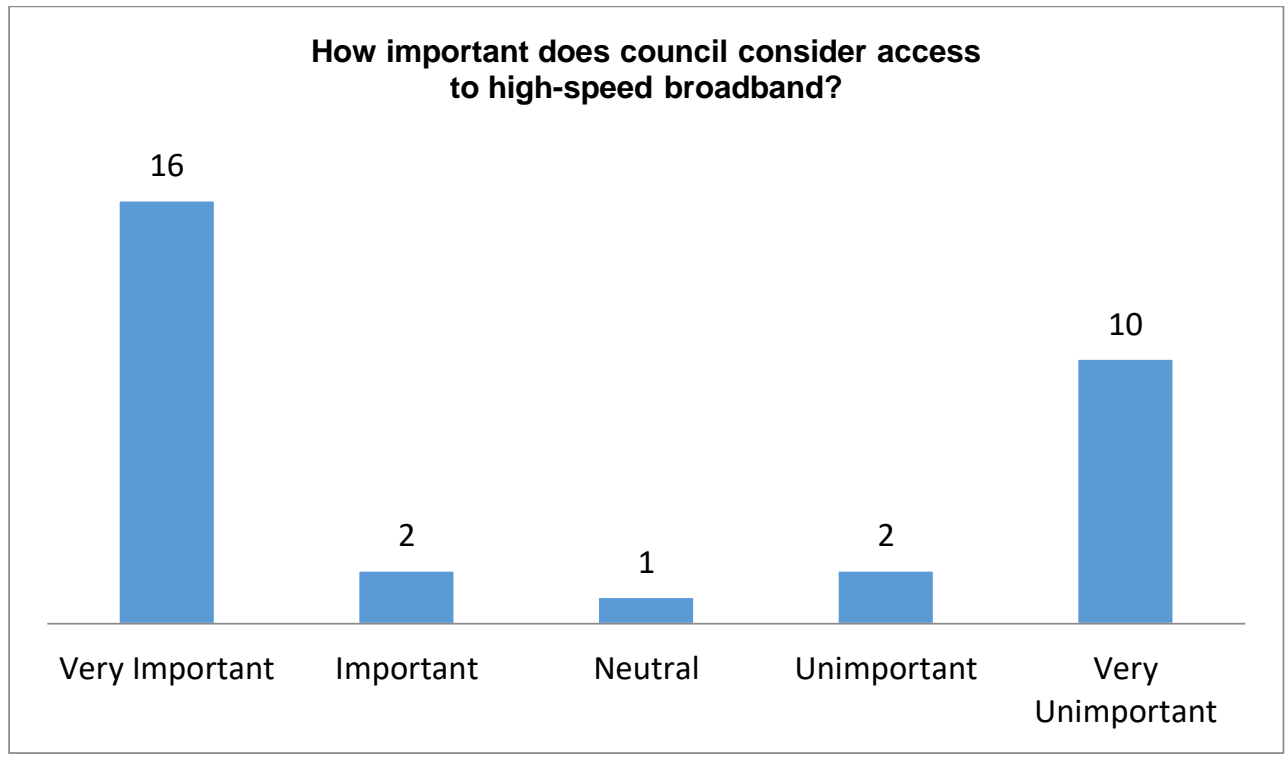

\section{Areas of involvement}

The following question asked, "In which areas of the council business do you expect to see the most implications of the high-speed broadband?" The choice of answers was: e-governance, socio-economic development, land use planning, and other. Respondents were allowed to choose multiple answers.

As shown in Figure 4, the majority of LGAs chose socio-economic development, followed by egovernance, and to a lesser extent, land use planning. A number of respondents ticked "other", and answers included:

- Opportunity through the physical construction of the NBN to upgrade community assets (footpaths and roads);

- Digital productivity and economic growth and competitiveness for the city;

- Internal services to field staff;

- Customer service;

- Community planning and engagement, new media enabled customer service, care programmes;

- $\quad$ Service delivery; and

- Innovation and digital divide. 
Figure 4: Areas of council business relevant to high-speed broadband

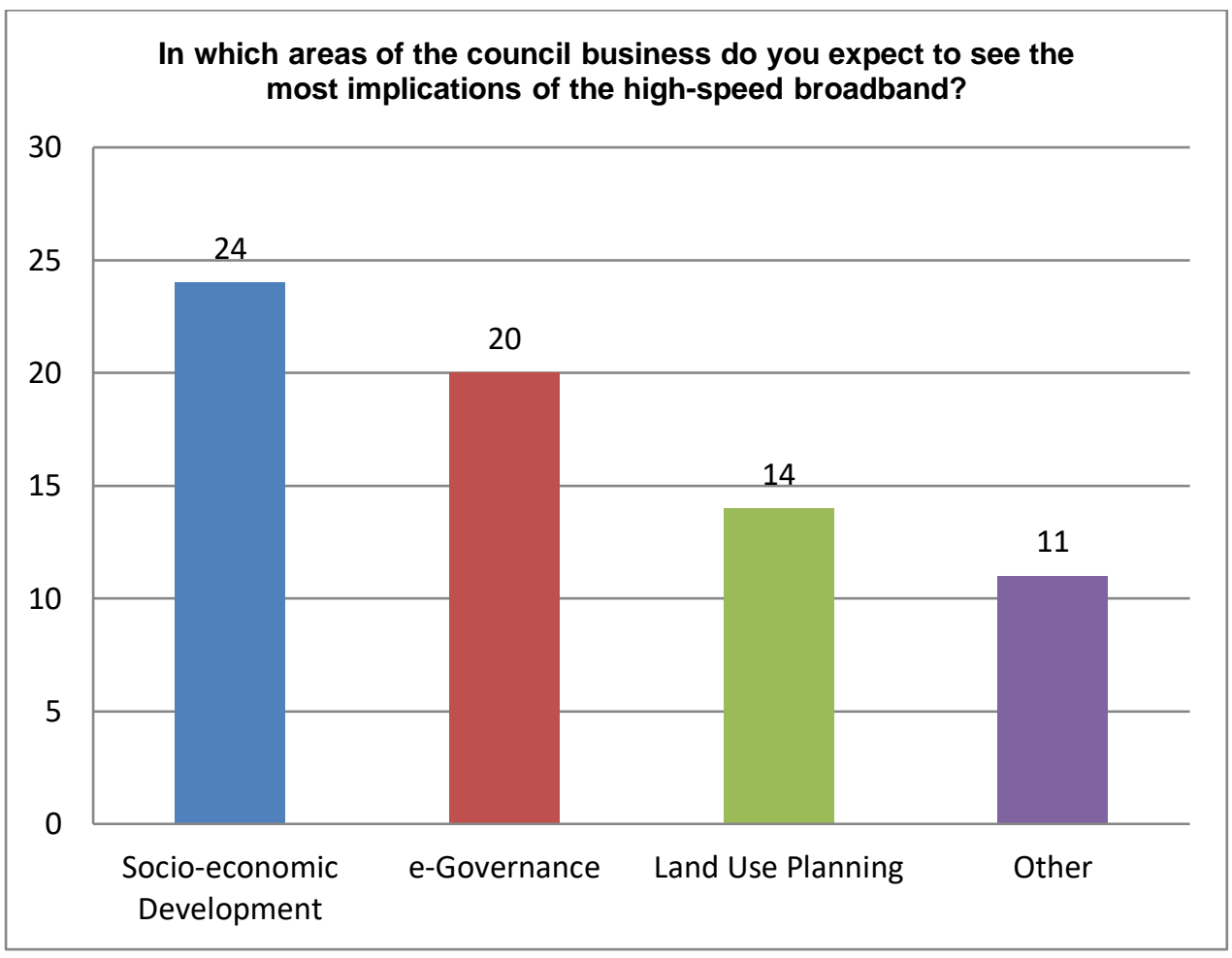

As is evident above, respondents felt that high-speed broadband was relevant to a wide diversity of council business, ranging from infrastructure (upgrading assets), to economic growth (digital productivity), customer service, and innovation.

An overview of the council's perception of the potential impact of telecommunication on local governments shows a broader understanding towards socio-economic implications. Such positive perception is founded in part on the literature generated over the last 10 to 15 years, describing the potential economic and social benefits of broadband infrastructure including increases in employment, economic output, and aggregate consumption at national, regional and local levels (Katz et al. 2010; Lee et al. 2005; Willson et al. 2009).

However, the survey also shows a less clear understanding when it comes to the link between telecommunication and land use planning. This is very much in line with the international literature as land use planning has been criticised for not having specific tools to deal with telecommunication infrastructure and its urban and regional implications. Land use planning's responses to ramifications of telecommunication such as new land uses (telecom hotels and telework centres) are also documented to be more varied than uniform (Alizadeh et al. 2014; Maeng and Nedovic-Budic 2004). Nevertheless, there is an emerging trend to regulate telecommunication-based land use issues and opportunities through zoning, and designation of special districts or industrial corridors accompanied by tax-based incentives (Maeng and Nedovic-Budic 2004). The online survey results suggest that quite a number of LGAs involved with the NBN early roll-out are not yet very familiar with such an emerging trend. 


\section{Variety of institutional arrangements in response to the NBN}

A wide range of institutional arrangements in response to the NBN were evident, some of which were based on federal funding initiatives, such as the Digital Local Government Programme, but others were quite innovative, and sometimes specific to a single council. Some findings were that the LGAs focused on the roll-out of fast broadband in the field of socio-economic development (e.g. providing multilingual interactive online services to better engage with their diverse local communities), then creating a digital hub, and joining a coalition of councils to promote digital economic strategies (also related to economic development) (Figure 5). Of note, LGAs had widely differing and often innovative responses to some terms, such as Digital Hub, with some LGAs taking this to mean full teleworking centres, and others to mean the provision of free internet in council libraries. As with the previous question, the respondents named a number of other institutional responses:

- We have been allocated grant funding to promote the benefits of the digital economy to SMEs;

- Lobbying Federal Government to include areas of municipality in roll-out;

- Community capacity development, including small business support;

- Series of digital economy projects underway; and

- Implemented Digital Local Government Programme.

A respondent, who chose to remain anonymous, answered: "Sought available funding for project; responded to multitude of NBN Co/contractor processes of installation; responded to stuff-ups [mistakes] of NBN Co/contractors; progressed digital readiness within council at operational level".

Figure 5: How LGAs have responded to the roll-out of fast broadband

How has your council responded to the roll-out of the NBN/fast broadband?

Hiring consultants to investigate or produce a digital economy strategy

Joining a coalition of councils to promote digital economic strategies

Creating a Digital Hub

Drafting or implementing a Digital Economy Strategy within council

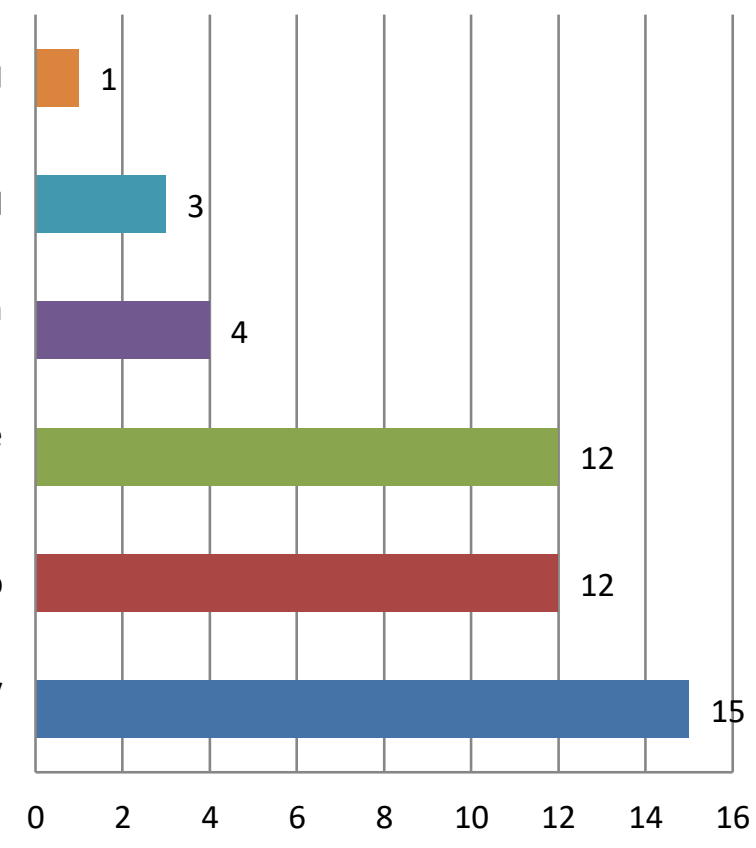


With regard to joining a coalition of councils, follow up interviews clarified that this largely referred to the membership of the organisation, Broadband Today Alliance (BTA), and not to a specific coalition of councils set up for this purpose. Four LGAs who were not part of the BTA however, ticked "joining a coalition of councils"; these included one LGA in Victoria, one in South Australia and two in Tasmania. Further clarification was sought with these four councils which showed that they were referring to sub-regional coalitions of councils with the neighbouring LGAs to share resources and exchange experiences in dealing with the telecommunication-based issues and opportunities. More specifically, local governments formed regional coalitions to join forces to be digital-ready (e.g. design and implement suitable online platforms and move away from paper-based services to online alternative formats), and incorporate e-governance opportunities with traditional local government responsibilities (Moody 2007; Weerakkody et al. 2007). Such attempts are supported by the literature arguing that e-government can create improved decision-making, increased government access, better public service delivery, internal efficiency; and support political accountability and participatory democracy (Irani et al. 2005; Jesuale 2006; Moody 2007).

However, research coming out of the US and Europe warns that while the beneficial prospects of telecommunication at all levels of government are high, they are penetrating at higher levels of government much more rapidly than at the local level (Evans-Cowley and Conroy 2009; Evans-Cowley and Hollander 2010). One obstacle seems to be the limited resources available at the local government level (Norris and Reddick 2013). Our survey results also point out links between different levels of resources available to different local governments and their approach towards the infrastructure. For example, the results show that all the LGAs that used consultants to produce their economic digital strategies were urban, whereas most regional LGAs had insufficient (financial) resources to hire external advisers. Having said this, the coalitions formed between regional LGAs were deemed as innovative ways of pooling together the limited resources available at the local level for better outcomes.

\section{Federally funded vs locally driven initiatives}

Many of the telecommunication-related initiatives, noted in the online survey responses, referred to tranches of federal (and state) funding for NBN related initiatives, such as the Digital Hubs, the Digital Enterprise Programme and Digital Local Government Programmes, many of which were still ongoing and were at various stages, depending on the roll-out stage of the LGA. However, the leadership role of the Federal Government (and state in some cases) is now in question following the recent policy and direction changes at the national level. In other words, it does not appear as if any of the above centrally funded initiatives will be renewed. In the absence of funding from higher levels of governments, it is highly unlikely that LGAs will be able to continue all of their telecommunication-related programmes. This could in turn slow down the process of capitalising on the positive socio-economic and e- 
governance implications of the new infrastructure, and then could result in Australia lagging behind a number of countries that try to claim their share of digital economy.

Having said this, it is important to acknowledge that a number of initiatives (including the multi-council collaborations, partnering with NBN Co, hiring external consultancies, etc.) to capitalise on the potential implications of the new infrastructure were quite independent of the higher levels of governments and based on locally driven forces. These locally driven initiatives are usually the ones that are under-studied and further attentions are required to fill the existing gaps in the literature around them. Nevertheless, when it comes to locally driven initiatives, there is a diverse pattern, as some LGAs seem to be far more active than others. Different levels of (pro) activity at local level might be explained by the fact that, in each LGA, the proportion of area in the roll-out differed widely, with some LGAs having very high proportions of their area able to access the NBN and others with very small proportions. Moreover, the selection of NBN sites within each LGA was apparently somewhat random, with some central business district areas, new industrial estates, residential areas and business parks missing out. Last but not least, previous studies (Alizadeh 2013, 2015) examining the socio-economic status of the early NBN release sites, show a great deal of diversity which could also be linked to the different levels of resources available for the relevant LGAs which could again explain the diverse level of local investment in the new infrastructure.

\section{Conclusion}

The paper started with the short history of the NBN in the Australian context, including the political ups and downs that have highly influenced the roll-out of the national infrastructure project since its introduction. It then continued with a brief review of broadband infrastructure and local planning in the international literature, followed by a summary of the federally driven initiatives offered in the Australian context to drive the socio-economic and e-governance implications of the new infrastructure. Such a comparison between the international vs Australian perspective noted the leadership role played by the Federal Government to speed up some of potential implications of the infrastructure. It was also noted that spatial implications of telecommunications were not properly promoted in Australia. A combination of above international and national investigation provided the theoretical foundation to analyse the Australian context and what has happened so far in the case of the NBN. In the empirical part of the paper, data were collected from the Australian local governments involved with the early NBN roll-out using an online survey plus desktop research.

Two notable outcomes of this study were the significant role played by the Federal Government in funding the NBN, enabling programmes at the local level; and the role of the NBN as an impetus in encouraging locally driven initiatives mostly through collaboration between local governments. 
First, many of the institutional arrangements responding to the NBN were based on Federal funding initiatives, such as the Digital Local Government Programme and the Digital Hubs Programme. These funding programmes played a significant role in directing the actions of local governments. Nonetheless, the individual LGAs often responded to the programmes in varied and innovative ways, such as partnering with the NBN and building on the funding programmes to improve the capacity of small to medium business enterprises. This highlights how federal funding can initiate local innovation and socio-economic development.

Second, the NBN also provided a trigger to encourage inter-council locally initiated collaboration, with LGAs either initiating and growing a national coalition of councils (i.e. the Broadband Today Alliance) or starting their own cooperative regional groups (i.e. Greater Western Sydney). Respondents largely recognised the value of the NBN to local governments, and even in some cases, councils not included in the NBN roll-out were involved in these coalitions.

To sum up, it is important to acknowledge that this paper is only a beginning in the mapping of the local planning implications of telecommunication infrastructure, and the role played by the Australian local governments in relation to the dynamics of the NBN over the last few years. The recent political decisions made around the NBN will leave the nation with a diverse range of access to telecommunication which means that implications will vary quite significantly based on the different level of access available at the local level.

\section{References}

Alizadeh, T. (2013) Towards the socio-economic patterns of the national broadband network rollout in Australia. Paper presented at the State of Australian Cities Conference, Sydney, 26-29 November. Available at: ttp://www.soacconference.com.au/wp-content/uploads/2013/12/Alizadeh-Movement.pdf

Alizadeh, T. (2015). The spatial justice implications of telecommunication infrastructure: The socio-economic status of early National Broadband Network rollout in Australia. International Journal of Critical Infrastructures, 11 (3), 278-296. doi: https://doi.org/10.1504/IJCIS.2015.072156

Alizadeh, T. and Shearer, H. (2015) A snapshot of high-speed broadband responses at local government level in Australia: A marriage between federally funded initiatives and locally driven innovations? Australian Planner, 52 (1), 42-50. doi: https://doi.org/10.1080/07293682.2015.1019754

Alizadeh, T., Sipe, N. (2013) Impediments to teleworking in live/work communities: Local planning regulations and tax policies. Urban Policy and Research, 31 (2), 208-224. doi: https://doi.org/10.1080/08111146.2013.779919

Alizadeh, T., Sipe, N. and Dodson, J. (2011) Metropolitan planning and NBN: A comparative policy analysis, Sydney vs. Brisbane. Paper presented at the State of Australian Cities National Conference, Melbourne, 29 November-2 December. Available at: http://www98.griffith.edu.au/dspace/bitstream/handle/10072/43549/74563_1.pdf?sequence=1

Alizadeh, T., Sipe, N. and Dodson, J. (2014) Spatial planning and high speed broadband: Australia's National Broadband Network and metropolitan planning. International Planning Studies, 19 (3-4), 359-378. doi: https://doi.org/10.1080/13563475.2014.965248

Aschauer, D.A. (1989) Is public expenditure productive? Journal of Monetary Economics, 23 (2), 177-200. doi: https://doi.org/10.1016/0304-3932(89)90047-0 
Barr, T. (2008) Broadband bottleneck: History revisited. Media International Australia, 129 (Nov), 129-139. doi: https://doi.org/10.1177/1329878X0812900113

Bekkers, V. (2003) e-Government and the emergence of virtual organizations in the public sector. Information Polity, 8, 89-101.

Button, K.J., Leitham, S., McQuaid, R.W. and Nelson, J.D. (1995) Transport and industrial and commercial location. Annals of Regional Science, 29 (2), 189-206. doi: https://doi.org/10.1007/BF01581806

DBCDE. (2010) National Broadband Network, overview. Canberra: Australian Government, Department of Broadband, Communications and the Digital Economy.

DBCDE. (2011a) Digital local programme guidelines-round two. Canberra: DBCDE.

DBCDE. (2011b) National digital economy strategy. Canberra: Australian Government, Department of Broadband Communications Digital Economy.

Doctor, R.D. (1994) Seeking equity in the national information infrastructure. Internet Research, 4 (3), 922.doi: https://doi.org/10.1108/10662249410798867

Duke, J. (2013) 900,000 premises may need to foot bill under NBN revision. Available at: http://www.propertyobserver.com.au/news/900000-premises-may-need-to-foot-bill-under-nbn-revisionarchers/2013111466370 [Accessed 19 November 2013].

Edmiston, K.D. (2003) State and local e-government prospects and challenges. The American Review of Public Administration, 33 (20), 20-45. doi: https://doi.org/10.1177/0275074002250255

Evans-Cowley, J. and Conroy, M.M. (2006) The growth of e-government in municipal planning. Journal of Urban Technology, 13 (1), 81-107. doi: https://doi.org/10.1080/10630730600752892

Evans-Cowley, J. and Conroy, M.M. (2009) Local government experiences with ICT for participation. In: Reddick, C.G. (ed) Strategies for local e-government adoption and implementation: Comparative studies (pp. 269-287). Hershey, PA: IGI Global. doi: https://doi.org/10.4018/978-1-60566-282-4.ch014

Evans-Cowley, J. and Hollander, J. (2010) The new generation of public participation: Internet-based participation tools. Planning Practice and Research, 25 (3), 397-408. doi: https://doi.org/10.1080/02697459.2010.503432

Evans-Cowley, J., Malecki, E.J. and McIntee, A. (2002) Planning responses to telecom hotels: What accounts for increased regulation of co-location facilities? Journal of Urban Technology, 9 (3), 1-18. doi: https://doi.org/10.1080/1063073022000044260

Ford, G.S. and Koutsky, T.M. (2005) Broadband and economic development: A municipal case study from Florida. Review of Urban \& Regional Development Studies, 17 (3), 216-229. doi: https://doi.org/10.1111/j.1467-940X.2005.00107.x

Frieden, R. (2005) Lessons from broadband development in Canada, Japan, Korea and the United States. Telecommunications Policy, 29 (8), 595-613. doi: https://doi.org/10.1016/j.telpol.2005.06.002

Galloway, L. (2007) Can broadband access rescue the rural economy? Journal of Small Business and Enterprise Development, 14 (4), 641-653. doi: https://doi.org/10.1108/14626000710832749

Given, J. (2008) Australia's broadband: How big is the problem? Media International Australia, 127 (May), 610. doi: https://doi.org/10.1177/1329878X0812700103

Gramlich, E.M. (1994) Infrastructure investment: A review essay. Journal of Economic Literature, 32 (3), 1176-1196.

Grubesic, T.H. (2010) Efficiency in broadband service provision: A spatial analysis. Telecommunications Policy, 34 (3), 117-131. doi: https://doi.org/10.1016/j.telpol.2009.11.017

Grubesic, T.H. (2012) The wireless abyss: Deconstructing the US national broadband map. Government Information Quarterly, 29 (4), 532-542. doi: https://doi.org/10.1016/j.giq.2012.05.006

Grubesic, T.H., Matisziw, T.C. and Murray, A.T. (2011) Market coverage and service quality in digital subscriber lines infrastructure planning. International Regional Science Review, 34 (3), 368-390. doi: https://doi.org/10.1177/0160017610386479 
Grubesic, T.H. and Murray, A.T. (2004) Waiting for broadband: Local competition and the spatial distribution of advanced telecommunication services in the United States. Growth and Change, 35 (2), 139-165. doi: https://doi.org/10.1111/j.0017-4815.2004.00243.x

Handy, S.L. and Mokhtarian, P.L. (1995) Planning for telecommuting: Measurement and policy issues. Journal of American Planning Association, 61 (1), 99-111. doi: https://doi.org/10.1080/01944369508975623

Hesham, M.A.-R. (2000) Multi-firm city versus company town: A micro foundation model of localization economies. Journal of Regional Science, 40, 755-771. doi: https://doi.org/10.1111/0022-4146.00197

Irani, Z., Love, P.E.D., Elliman, T., Jones, S. and Themistocleous, M. ( 2005) Evaluating e-government: learning from the experiences of two UK local authorities. Information Systems Journal, 15 (1), 61-82. doi: https://doi.org/10.1111/j.1365-2575.2005.00186.x

Jesuale, N. (2006) Spectrum policy issues for state and local government. International Journal of Network Management, 16 (2), 89-101. doi: https://doi.org/10.1002/nem.607

Katz, R.L., Vaterlaus, S., Zenhäusern, P. and Suter, S. (2010) The impact of broadband on jobs and the German economy. Intereconomics, 45 (1), 26-34. doi: https://doi.org/10.1007/s10272-010-0322-y

Lee, H., Oh, S. and Shim, Y. (2005) Do we need broadband? Impacts of broadband in Korea. Info, 7 (4), $47-56$. doi: https://doi.org/10.1108/14636690510607295

Mack, E.A., Anselin, L. and Grubesic, T.H. (2011) The importance of broadband provision to knowledge intensive firm location. Regional Science Policy \& Practice, 3 (1), 17-35. doi: https://doi.org/10.1111/j.1757-7802.2011.01026.x

Maeng, D.-M. and Nedovic-Budic, Z. (2004) Chicago and Seoul: a comparative study of the impact of information and communications technologies on urban land use and regulation. Journal of Urban Technology, 11 (2), 61-92. doi: https://doi.org/10.1080/10630730412331297314

Martin, P. (1999) Public policies, regional inequalities and growth. Journal of Public Economics, 73 (1), $85-97$. doi: https://doi.org/10.1016/S0047-2727(98)00110-8

Martin, P. and Rogers, C.A. (1995) Industrial location and public infrastructure. Journal of International Economics, 39 (3-4), 335-362. doi: https://doi.org/10.1016/0022-1996(95)01376-6

McNulty, D.D. (2008) The adequacy of response rates to online and paper surveys: What can be done? Assessment \& Evaluation in Higher Education, 33 (3), 301-314. doi: https://doi.org/10.1080/02602930701293231

Middleton, C. (2009) Can broadband support environmental sustainability? Telecommunication Journal of Australia, 59 (1), 10.11-10.14.

Middleton, C. and Chang, S. (2008) The adoption of broadband internet in Australia and Canada In: Dwivedi, Y.K., Papazafeiropoulou, A. and Choudrie, J. (eds) Handbook of research on global diffusion of broadband data transmission (pp. 820-842). Harrisburg, PA: IGI Global. doi:https://doi.org/10.4018/978-1-59904-851-2.ch049

Moody, R. (2007) Assessing the role of GIS in e-government: A tale of e-participation in two cities. Electronic Government: Lecture Notes in Computer Science, 4656, 354-365.

NBN Co. Ltd. (2010a) Corporate plan 2011-2013. Canberra: NBN Co. Ltd.

NBN Co. Ltd. (2010b) History of NBN Co. Available at: http://www.nbnco.com.au/aboutus/index.html?icid=pub:hme:about:bod:txt [Accessed 12 February 2012].

NBN Co. Ltd. (2011) NBN Co releases 12-month national rollout plan. Available at: http://www.nbnco.com.au/corporate-information/media-centre/media-releases/nbn-co-releases-12month-national-rollout-plan.html [Accessed 5 December 2016].

NBN Co. Ltd. (2012a) NBN Co announces next rollout locations. Available at: http://www.nbnco.com.au/corporate-information/media-centre/media-releases/nbn-co-announces-nextrollout-locations.html [Accessed 5 December 2016].

NBN Co. Ltd. (2012b) Three year rollout plan for NBN announced. Available at: http://www.nbnco.com.au/corporate-information/media-centre/media-releases/nbn-co-announces-threeyear-rollout-plan.html [Accessed 5 December 2016]. 
Nirmalathas, A. (2014) What now for the NBN as taxpayer investment is capped? Available at: https://theconversation.com/what-now-for-the-nbn-as-taxpayer-investment-is-capped-26703 [Accessed 5 December 2016].

Norris, D.F. and Reddick, C.G. (2013) Local e-government in the United States: Transformation or incremental change? Public Administration Review, 73 (1), 165-175. doi: https://doi.org/10.1111/j.15406210.2012.02647.x

Rowe, B. (2003) Rural technology deployment and access: Successes upon which to build. Government Information Quarterly, 20 (2), 85-93. doi: https://doi.org/10.1016/S0740-624X(03)00034-0

Savage, S.J. and Waldman, D. (2005) Broadband Internet access, Awareness, and use: Analysis of United States household data Telecommunications Policy, 29 (8), 615-633. doi: https://doi.org/10.1016/j.telpol.2005.06.001

Seitz, H. (1995) The productivity and supply of urban infrastructures. Annals of Regional Science, 29 (2), 121141. doi: https://doi.org/10.1007/BF01581802

Simpson, D.M. (2005) Use of web technologies by US planning agencies: Results from a national benchmarking survey. In: ICMA (ed) US municipal year book (pp. 22-26). Washington, D.C: International City/County Management Association.

Steyaert, J. (2000) Local governments online and the role of the resident - government shop versus electronic community. Social Science Computer Review, 18, 3-16. doi: https://doi.org/10.1177/089443930001800101

Strategic Networks Group. (2003) Economic impact study of the South Dundas township fibre network. London: Department of Trade and Industry (DTI). Available at: http://www.sngroup.com/wpcontent/uploads/2011/03/DTI-SD-Case-Study_Final_Issued-June-27-2003.pdf

Tucker, R. (2010) Broadband facts, fiction and urban myths. Telecommunications Journal of Australia, 60 ( 3), 1-15.doi: https://doi.org/10.2104/tja10043

Turnbull, M. (2014) NBN Co to roll out new multi-technology mix. Available at: http://www.minister.communications.gov.au/malcolm_turnbull/news/nbn_co_to_roll_out_new_multitechnology_mix\#.VMceGi6t4lA [Accessed 27 January 2015].

Turner, A. (2013) NBN hookups put on hold. Available at: http://www.smh.com.au/digital-life/digital-lifenews/nbn-hookups-put-on-hold-20131106-2wzz4.html [Accessed 19 November 2013].

Weerakkody, V., Jones, S. and Olsen, E. (2007) e-Government: A comparison of strategies in local authorities in the UK and Norway. International Journal of Electronic Business, 5 (2), 141-159. doi: https://doi.org/10.1504/IJEB.2007.012970

Willson, P., Marshall, P. and McCann, J. (2009) Evaluating the economic and social impact of NBN. Paper presented at the 20th Australasian Conference on Information Systems, Melbourne, 2-4 Dec. 